\title{
HUBUNGAN GENDER DENGAN HASIL BELAJAR MATA KULIAH METODOLOGI PENELITIAN PADA MAHASISWA TBI IAIN TAKENGON TA.2019/2020
}

\author{
Rahmahidayati Sari \\ IAIN Takengon Aceh
}

\begin{abstract}
This study looked at the relationship between gender and learning outcomes in the research methodology subject for TBI students TA. 2019/2020. Gender is one part of the psychological aspect that comes from an individual that will affect a person's learning success. The purpose of this study was to see the relationship between gender and student learning outcomes in the research methodology course TA.2019/2020. The population of this study were the fifth semester students of IAIN Takengon, while the sampling technique was saturated sampling, so that all members of the population were used as samples as much 25 students. This research was conducted using a quantitative research approach by looking at the relationship between the two variables. The data analysis technique in this study used the product moment correlation formula. From the results of the data analysis, it was found that the calculated $r$ value is 0.15 and the $r$ table is 0.3809 so that the $r$ count is smaller than the $r$ table. And the conclusion of this study is that there is no relationship between gender and the learning outcomes of the research methodology course for TBI TA students. 2019/2020 at IAIN Takengon.
\end{abstract}

Keywords: gender, learning outcomes, research methodology

\section{PENDAHULUAN}

Hasil belajar merupakan salah satu indikator menentukan keberhasilan belajar dan proses pembelajaran. Selain itu, hasil belajar sebagai bahan pertimbangan menentukan siswa dapat melanjutkan ke tingkat pendidikan selanjutnya. Dengan melihat hasil belajar akan memberikan umpan balik kepada guru, siswa serta pihak yang berkepentingan melakukan perbaikan atau melanjutkan apa yang telah dilakukan oleh guru dan lembaga pendidikan.

Keberhasilan belajar yang dilakukan dalam lembaga pendidikan sesuai dengan tujuan pembelajaran. Ada beberapa faktor yang mempengaruhi keberhasilan belajar bagi siswa/ peserta didik. Ada dua faktor yang mempengaruhi keberhasilan siswa dalam belajar yaitu (Dessy Mulyani, 2013: 38): Faktor ekstern (yang berasal dari luar diri siswa) dan intern (dari dalam diri siwa). Faktor ekstern yaitu faktor yang berasal dari luar diri individu seperti lingkungan keluarga, sekolah dan masyarakat, sedangan faktor intern yaitu tiga tahap bagian yaitu faktor kelelahan (kelelahan jasmani dan kelelahan rohani), faktor jasmaniah (kesehatan, cacat tubuh) dan faktor psikologis (intelegensi, perhatian, minat, bakat, motif, kematangan, keterampilan dan kesiapan belajar). 
Salah satu faktor psikis/ kejiwaan berpengaruh kepada hasil belajar adalah gender/ perbedaan gender. Faktor psikis/ kejiwaan gender berpengaruh prestasi belajar siswa karena gender merupakan dimensi sosiokultural dan psikologis dari pria dan wanita (Santrock, 2007:194). Faktor gender yang merupakan bagian dari faktor psikis/ kejiwaan yang mempengaruhi prestasi belajar, tentunya akan berpengaruh kepada hasil belajar siswa.

Dengan adanya perbedaan gender yang ada dalam sebuah kelas maka sebaiknya guru/ tenaga pendidik memberikan metode mengajar yang mempertimbangkan hal-hal yang mendasar seperti perbedaan gender tersebut. Namun perbedaan gender bukanlah hal yang dapat menjadikan guru/ tenaga pendidik melakukan pembelajaran dengan metode yang berbeda sehingga di Indonesia secara umum pembelajaran dilakukan secara klasikal. Pembelajaran klasikal merupakan pembelajaran yang dilakukan pada waktu, materi, tempat yang sama dengan beranggapan siswa/ peserta didik tidak berbeda (Sugeng Apriadi, 2012: 39).

Penelitian yang dilakukan ini bertujuan untuk mengetahui apakah terdapat hubungan antara gender dengan hasil belajar mata kuliah metodologi penelitian pada mahasiswa TBI di IAIN Takengon TA 2019/2020 dengan rumusan masalah: "Apakah terdapat hubungan antara gender dengan hasil belajar mata kuliah metodologi penelitian pada mahasiswa TBI IAIN Takengon TA 2019/2020?"

\section{METODE PENELITIAN}

Penelitian yang berjudul hubungan gender dengan hasil belajar mahasiswa pada mata kuliah metodologi penelitian pada mahasiswa TBI IAIN Takengon menggunakan pendekatan kuantitatif. Penelitian kuantitatif adalah penelitian yang berdasarkan kepada pendeketan positivism, digunakan untuk meneliti pada populasi dan sampel tertentu, teknik pengambilan sampel pada umumnya digunakan dengan cara random, pengumpulan data menggunakan instrument penelitian, analisis data bersifat kuantitatif/ statistic dengan tujuan untuk menguji hipotesis yang telah ditetapkan (Sugiyono, 2012:13).

Menurut (Nana Syaodih Sukmadinata. 2011: 14), penelitian korelasional ditujukan untuk mengetahui hubungan suatu variabel dengan variabel-variabel lain. Hubungan antara satu variabel dengan beberapa variabel lain dinyatakan dengan besarnya koefisien korelasi dan keberartian (signifikansi) secara statistik.

Penelitian ini menggunakan populasi yaitu mahasiswa TBI IAIN Takengon yang mengambil mata kuliah metodologi penelitian pada tahun ajaran 2019/2020. Jumlah mahasiswa TBI IAIN Takengon tahun ajaran 2019/2020 sebanyak 25 orang. Pengambilan sampel dalam penelitian ini menggunakan teknik sampling jenuh yang artinya seluruh anggota populasi dijadikan sebagai sampel dalam penelitian (Sugiyno, 2012: 61-63). Dengan pengambilan sampel dengan teknik ini maka seluruh mahasiswa TBI yang 
mengambil mata kuliah metodologi penelitian pada tahun ajaran 2019/ 2020 sebanyak 25 orang dijadikan sebagai sampel dalam penelitian ini.

Penelitian ini menggunakan instrument penelitian berupa dokumentasi. Dokumentasi adalah salah satu instrument penelitian dengan menggunakan catatan ataupun laporan yang dijadikan sebagai bukti ataupun data dalam penelitian. Data yang dibutuhkan dalam penelitian ini diambil dari dokumen yang dimiliki oleh dosen mata kuliah metodologi penelitian berisi nilai dari masing-masing mahasiswa.

Penelitian yang dilakukan menggunakan pendekatan kuantitatif dengan jenis korelasional. Dengan jenis penelitian ini maka teknik pengolahan data yang dilakukan menggunakan pengolahan data univariat dan bivariate. Analisis data yang digunakan dengan menggunakan central tendency dan variabilitas. Sedangkan untuk Teknik pengolahan data bivariate, menggunakan analisis data pearson product moment dan analisis regresi linear sederhana. Analisis data pearson product moment digunakan untuk mengetahui apakah terdapat hubungan antara variable $\mathrm{X}$ dan variable $\mathrm{Y}$. sedangkan analisis regresi linear sederhana digunakan untuk melihat kekuatan hubungan antara variable $\mathrm{X}$ dan variable $\mathrm{Y}$.

\section{KAJIAN TEORI}

\section{A. Gender}

Konsep gender adalah konsep yang digunakan untuk mengidentifikasi perbedaan antara laki-laki dan perempuan dilihat dari segi sosial-budaya atau nonbiologis. Dengan bahasa yang lengkap, gender adalah pandangan masyarakat tentang perbedaan fungsi, peran dan tanggungjawab antara laki-laki dan perempuan, sebagai hasil konstruksi sosialkultural yang tumbuh dan disepakati oleh masyarakat dengan proses yang sangat panjang, bisa berubah dari waktu kewaktu, tempat ke tempat, bahkan dari kelas-ke kelas sesuai perkembangan zaman (Nur Aisyah, 2013: 206-207). Gender meyoroti aspek peran, fungsi dan tanggung jawab di dalam menjelaskan perbedaan antara laki-laki dan perempuan (Syaefudin Achmad, 2019: 75). Gender adalah persoalan nature dan nurture. Dari aspek nature, terdapat perbedaan antara laki-laki dan perempuan, demikian juga dari sisi nurture. Hanya saja, jika yang natural bercorak kodrati (taken for granted), maka yang nurture merupakan hasil konstruksi sosial dan budaya masyarakat tentang perbedaan lakilaki dan perempuan (Andik Wahyun Muqoyyidin, 2013: 498).

\section{B. Hasil Belajar}

Pembelajaran yang dilakukan oleh setiap siswa/ peserta didik memiliki tujuan akhir yang dapat dinilai dan diamati yang disebut dengan hasil belajar. Hasil belajar yang diperoleh mahasiswa merupakan suatu bentuk keberhasilan atas usaha-usaha yang telah dilakukan mahasiswa dalam proses belajar (Triave Nuzila Zahri,dkk, 2017: 22). Hasil belajar merupakan hasil yang diperoleh seseorang atau pola perubahan dan sikap seseorang setelah melakukan kegiatan belajar dalam aspek kognitif, afektif dan psikomotorik yang dinyatakan dalam simbol, angka dan tulisan (Arie Wahyuni, Prihadi 
Kurniawan, 2018:3). Hasil belajar mahasiswa yang ada di Perguruan Tinggi dapat dilihat dengan nilai akhir mahasiswa untuk setiap mata kuliah dalam skala 5 yaitu A, B, C, D dan E. Nilai dalam bentuk huruf tersebut dapat diubah dalam bentuk angka 0-4 dengan A nilai tertinggi 4 dan E nilai terendah yaitu 0 .

\section{HASIL PENELITIAN DAN PEMBAHASAN}

A. Hasil Penelitian

1. Variabel X (Gender)

variabel $\mathrm{X}$ adalah variabel bebas yang membicarakan tentang gender. Dari hasil penelitian yang dilakukan didapatkan data sepeerti di bawah ini:

Tabel 1. Persentase Jumlah Mahasiswa Dilihat dari Gender

\begin{tabular}{|l|l|l|}
\hline Jenis kelamin & Jumlah & Persentase \\
\hline Perempuan & 22 & $88 \%$ \\
\hline Laki-laki & 3 & $12 \%$ \\
\hline
\end{tabular}

Tabel di atas menunjukkan hasil bahwa terdapat 3 orang mahasiswa laki-laki dengan persentase sebesar $12 \%$. Mahasiswa perempuan yang ada dalam kelompok ini sebanyak 22 orang dengan persentase sebesar $88 \%$.

2. Variabel Y ( Hasil Belajar)

Variabel Y dalam penelitian ini adalah hasil belajar pada mata kuliah metodologi penelitian. Untuk hasil belajar pada mata kuliah metodologi penelitian berdasarkan nilai akhir pada mata kuliah dengan 5 skala yaitu: A B C D dan E. Nilai dalam bentuk huruf selanjutnya diubah menjadi bentuk angka yaitu: 4321 dan 0 .

Dari penelitian yang dilakukan didapatkan hasil belajar mahasiswa pada mata kuliah metodologi penelitian adalah sebagai berikut:

Table 2. Persentase Nilai Mata Kuliah Metodologi Penelitian

\begin{tabular}{|l|l|l|}
\hline Nilai & Jumlah & Persentase \\
\hline A (4) & 2 orang & $8 \%$ \\
\hline B (3) & 19 orang & $76 \%$ \\
\hline C (2) & 4 orang & $16 \%$ \\
\hline D (1) & 0 orang & $0 \%$ \\
\hline E (0) & 0 orang & $0 \%$ \\
\hline
\end{tabular}

Dengan hasil table 2. persentase nilai mata kuliah metodologi penelitian di atas diketahui dari 25 orang mahasiswa hanya 2 orang yang mendapatkan nilai A dengan persentase $8 \%$. Mahasiswa yang mendapatkan nilai B ada 19 orang yaitu sebesar $76 \%$. Mahasisawa yang mendapatkan nilai $\mathrm{C}$ adalah sebanyak 4 orang dengan persentase sebesar $16 \%$. Dan tidak ada satu orangpun mahasiswa yang mendapatkan nilai d dan E sehingga persentasenya $0 \%$. 
Dari nilai yang didapatkan berdasarkan tabel di atas, didapatkan untuk mata kuliah metodologi penelitian nilai rata-ratanya (mean) adalah 2,92 untuk skala 0 sampai dengan 4. Nilai tengah (median) untuk nilai mata kuliah mata kuliah metodologi penelitian di atas adalah 3 dan nilai yang paling banyak muncul (modus) pada nilai mata kuliah metodologi penelitian ini adalah 3 .

Nilai mata kuliah metodologi penelitian mahasiswa laki-laki dapat digambarkan dengan table di bawah ini:

Tabel 3. Persentase Nilai Mata Kuliah Metodologi Penelitian bagi

Mahasiswa laki-laki

\begin{tabular}{|l|l|l|}
\hline Nilai & Jumlah (orang) & Persentase (\%) \\
\hline A (4) & 0 & 0 \\
\hline B (3) & 3 & 100 \\
\hline C (2) & 0 & 0 \\
\hline D (1) & 0 & 0 \\
\hline E (0) & 0 & 0 \\
\hline
\end{tabular}

Dari tabel 3 di atas didapatkan bahwa mahasiswa laki-laki ada 3 orang. Semua mahasiswa laki-laki tersebut mendapatkan nilai $\mathrm{B}$ dan persentase mahasiswa yang mendapatkan nilai B (3) adalah 100\%. Dan 0\% bagi nilai A (4), C (2), D (1) dan E (0).

Tabel di atas memberikan gambaran kepada peneliti bahwa hasil belajar kepada peneliti, hasil belajar mereka adalah B (3). Sedangkan nilai untuk mahasiswa perempuan, mereka memiliki nilai yang lebih variatif. Nilai yang didapatkan oleh mahasiswa perempuan disajikan dalam bentuk tabel 4 di bawah ini:

Tabel 4. Persentase Nilai Mata Kuliah Metodologi Penelitian bagi

Mahasiswa Perempuan

\begin{tabular}{|l|l|l|}
\hline Nilai & Jumlah (orang) & Persentase (\%) \\
\hline A (4) & 2 & 9,1 \\
\hline B (3) & 16 & 72,7 \\
\hline C (2) & 4 & 18,2 \\
\hline D (1) & 0 & 0 \\
\hline E (0) & 0 & 0 \\
\hline
\end{tabular}

Dari tabel 4 di atas didapatkan bahwa mahasiswa perempuan ada 22 orang. Mahasiswa perempuan yang mendapatkan nilai A (4) sebanyak 2 orang dengan persentase sebesar 9,1\%. Mahasiswa yang mendapatkan nilai B (3) sebanyak 16 orang dengan persentase $72,7 \%$. Sedangkan mahasiswa perempuan yang mendapatkan nilai $\mathrm{C}$ (2) ada sebanyak 4 orang dengan persentase 18,2 \%.

Hubungan variabel X (gender) dengan variabel Y (Hasil Belajar)

Dari penelitian yang telah dilakukan, didapatkan hasil dari pengolahan excel bahwa hubungan antara variabel $\mathrm{X}$ dengan variabel $\mathrm{Y}$ adalah sebesar 0,15 yang artinya adalah: 
hubungan antar variabel X ( gender) dengan variabel Y (Hasil Belajar) adalah sebesar 0,15 . Berarti koefisien $r$ dari 2 variabel $X$ (gender) dan variabel $Y$ (hasil belajar) adalah 0,15. Dan berdasarkan tabel $\mathrm{r}$ product moment didapatkan untuk $\mathrm{N}=25$ dengan $\alpha=0.05$ maka didapatkan $r$ tabel adalah 0,3809. Kemudian bandingkan $r$ hitung dengan $r$ tabel, ternyata dari hasil yang telah didapatkan, $r$ hitung lebih kecil dari pada $r$ tabel. Karena $r$ hitung lebih kecil dari $r$ tabel maka hipotesis alternatif ditolak dan hipotesis nol diterima. Dengan demikian dapat disimpulkan bahwa tidak terdapat hubungan antara variabel $\mathrm{X}$ (gender) dengan variabel Y ( hasil belajar) mata kuliah metodologi penelitian pada mahasiswa TBI TA. 2019/2020.

B. Pembahasan

Dari hasil penelitian pada halaman sebelumnya diketahui ada 2 variabel untuk penelitian ini yaitu variabel $\mathrm{X}$ tentang gender dan variabel $\mathrm{Y}$ tentang hasil belajar.

\section{Variabel X (Gender) dan variabel Y ( Hasil Belajar)}

Dilihat dari hasil penelitian di atas diketahui bahwa ada mahasiswa laki-laki yang ditandai dengan nomor 1 dan mahasiswa perempuan ditandai dengan nomor 2 . Mahasiswa laki-laki yang berjumlah 3 orang diberikan persentase sebesar $12 \%$ dari jumlah keseluruhan mahasiswa yaitu 25 orang. Sedangkan mahasiswa perempuan adalah sebanyak 22 orang dengan persentase sebesar $88 \%$. Angka yang telah tertera tersebut, jumlah mahasiswa perempuan lebih banyak dari pada mahasiswa laki-laki. Dengan selisih persentase antara kedua gender tersebut adalah $76 \%$.

Dari hasil penelitian yang telah dilakukan didapatkan bahwa $100 \%$ mahasiswa lakilaki mendapatkan nilai B dengan menggunakan skala 5. Penulis menyimpulkan, dari hasil yang didapatkan tersebut bahwa kemampuan mahasiswa laki-laki untuk mata kuliah metodologi penelitian ini sama. Sedangkan mahasiswa perempuan memiliki nilai yang lebih bervariasi pada mata kuliah metodologi penelitian. Ini memberikan gambaran kepada penulis bahwa kemampuan mahasiswa perempuan untuk mata kuliah metodologi penelitian ada yang tinggi, sedang dan rendah. Yang dibuktikan dengan nilai mahasiswa perempuan ada yang mendapatkan nilai yang tertinggi untuk skala 5 yaitu A. mahasiswa perempuan juga ada yang mendapatkan nilai B yang dinilai memiliki kemampuan sedang dan terdapat beberapa mahasiswa perempuan yang mendapatkan nilai $\mathrm{C}$ yang dinilai kemampuan rendah. Berarti mahasiswa perempuan prodi TBI pada mata kulian metodologi penelitian lebih merata dan tidak menumpuk pada satu nilai tertentu.

\section{Hubungan Variabel X (Gender) dengan variabel Y ( Hasil Belajar)}

Dari hasil analisis data hubungan antara variabel X (Gender) dengan variabel Y (Hasil Belajar) pada mahasiswa TBI pada mata kuliah metodologi penelitian didapatkan koefisien korelasinya adalah 0,15 . Jika dilihat dari tabel ancer-ancer yang dikemukakan oleh Suharsimi Arikunto bahwa hubungan antara 2 variabel dengan indeks korelasi 0.000.20 maka dikategorikan korelasi atau hubungan antara kedua variabel tersebut sangat rendah. Diartikan dengan korelasi/ hubungan yang sangat rendah tersebut maka bisa 
dikatakan hubungan keduanya tidak terlalu mempengaruhi antara satu variabel dengan variabel yang lain.

Jika dibandingkan dengan $r$ tabel didapatkan kesimpulan bahwa tidak terdapat hubungan antara gender dengan hasil belajar mata kuliah metodologi penelitian pada mahasiswa TBI IAIN Takengon TA. 2020/2021. Berarti untuk mahasiswa prodi TBI TA. 2020/2021 faktor gender bukanlah faktor yang mempengaruhi hasil belajar pada mata kuliah metodologi penelitian, walaupun dalam teori disebutkan bahwa gender merupakan salah satu factor keberhasilan dalam belajar. Gender merupakan salah satu faktor keberhasilan belajar sesorang dari segi psikologis.

Keberhasilan belajar bagi mahasiswa TBI TA. 2020/2021 pada mata kuliah metodologi penelitian dipengaruhi oleh faktor-faktor lainnya. Faktor lain tersebut berasal dari intern (dalam diri) seseorang yaitu fisik, psikologis dan kelelahan dalam belajar. Walaupun gender termasuk kepada faktor psikologis, tetapi gender tidak mempengaruhi yang mempengaruhi hasil belajar mahasiswa. Ada banyak faktor psikologis lainnya yang mempengaruhi hasil belajar.

Selain faktor intern, terdapat faktor ekstern (luar diri) seseorang yang mempengaruhi hasil belajar. Faktor ekstern tersebut adalah faktor keluarga, sekolah dan masyarakat.

\section{SIMPULAN}

Dari penelitian yang dilakukan maka dapat disimpulkan bahwa tidak terdapat hubungan antara gender dengan hasil belajar mata kuliah metodologi penelitian pada mahasiswa TBI IAIN Takengon 2019/2020.

Ada beberapa saran yang diberikan yaitu:

1. Melakukan proses pembelajaran, sebaiknya dosen memberikan metode yang disesuaikan dengan karakteristik mahasiswa yang diajarnya termasuk dengan memperhatikan perbedaan gender dalam kelas yang diajar.

2. Penelitian ini baru sekedar membahas tentang hubungan gender dengan hasil belajar yang dilakukan, selanjutnya peneliti mengharapkan adanya penelitian lanjutan yang berhubungan dengan perbedaan gender dalam proses pembelajaran di perguruan tinggi

3. Peneliti menyarankan kepada pembuat keputusan di perguruan tinggi untuk mempertimbangkan perbedaan gender dalam proses pembelajaran.

\section{DAFTAR PUSTAKA}

Akdon, (2008)., Aplikasi Statistika \& Metode Penelitian., Bandung., Dewa Ruchi 
Andik Wahyun Muqoyyidin, (2013), Wacana Kesetaraan Gender: Pemikiran Islam Kontemporer tentang Gerakan Feminisme Islam, Jurnal Al-Ulum Volume. 13 Nomor 2

Arie Wahyuni, Prihadi Kurniawan, (2018), Hubungan Kemampuan Berpikir Kreatif Terhadap Hasil Belajar Mahasiswa, Jurnal Matematika Vol. 17, No. 2

Dessy Mulyani, (2013), Hubungan Kesiapan Belajar Siswa dengan Prestasi Belajar Jurnal Konselor, Volume 2 Nomor 1

N. Aisyah, (2013), Relasi Gender dalam Institusi Keluarga (Pandangan Teori Sosial dan Feminis), Jurnal: Muwazah, Volume 5 Nomor 2

Slameto. 2010. Belajar dan Faktor Faktor yang Mempengaruhinya. Jakarta: Rineka Cipta.

Sugeng Apriadi, Syahrul Syah Sinaga, (2012), Strategi Pembelajaran Drum pada Junior Kids Secara Klasikal di Gilang Ramadhan Studio Band (GRSB) Semarang, Jurnal Seni Musik, UNS, Volume 1 Nomor 1

Syaefudin Achmad, (2019), Membangun Pendidikan Berwawasan Gender, YINYANG: Jurnal Studi Islam, Gender dan Anak, volume 1 nomor 1

Triave Nuzila Zahri1, dkk, (2017), Hubungan Gaya Belajar dan Keterampilan Belajar dengan Hasil Belajar Mahasiswa, Jurnal: Konselor, Volume 6 Number 1 